\title{
SCHOOL OF NEPALESE ARCHITECTURE
}

\author{
Shree Hari Thapa*1
}

\begin{abstract}
Architecture is an art of creation for the shelter of human beings. The shelter is called a secured place by the fierce animals, natural calamity, and with complete privacy. The school of architecture is distinguished in its use of construction material, skill, techniques, technology, form including the aspiration of the human being on the geographical strata. The technology and tradition of the construction of a building with certain forms and pattern are influenced by the climate, time, situation, and native construction material. Similarly, the migrants, traders, pilgrimage and travelers had transferred knowledge of tradition and technology with the principle of design philosophy from one place to another. The local or indigenous peoples, who lived or inhabit in the region with climate and geological strata, house form and pattern is varied due to the availability of indigenous construction material. The settlement pattern and the design philosophy of the houses in Nepal are geographically divided into three different regions due to its distinctive ways of construction.
\end{abstract}

Keywords : Geographical strata, indigenous construction material, thermal character, familiarize, skill, thermal insulation

\section{Background}

The location of Nepal is in between $80^{\circ} 15^{\prime}$ East to $88^{\circ} 15^{\prime}$ East longitude and $26^{\circ} 20^{\prime}$ North to $30^{\circ} 16^{\prime}$ North latitude (Shrestha, 2024, p. 1). The country occupies $0.3 \%$ of the total land mass of the earth while it shares $10 \%$ of the earth in biodiversity because, the climatic condition of Nepal is rapidly change within $200 \mathrm{Km}$ from South to North. The NorthSouth span is approximately $165-230 \mathrm{Km}$ and East West span is approximately $900 \mathrm{Km}$ (Shrestha, 2024, p. 1).

Nepal is a small country known by its natural, cultural, and ethnic diversity. The natural sources are the gift to all civilian of Nepal. The allure topography of Nepal has diversified in forest, water resources, soil or land, and minerals. Similarly, it has inhabitation of 125 ethnicities and its 123 distinct languages are spoken by different ethnic groups, such as Khasa, Tamang, Newar, Gurung, Tharu, Magar, Rai, Sherpa, Thakali, Sunuwar, Limbu, Dhimal, Kumal, and so on (Centre bureau of Statics, 2011) within the sort span.

All ethnic communities have their unique feature in all sectors of life; distinct ceremonies from birth to death and food habits as well as own traditional skills, knowledge and technology practiced in the house construction using indigenous construction materials. The construction materials are trees (evergreen, deciduous, and coniferous), stone, slate,

Senior Instructor, Thapathali Campus

Corresponding author

E-mail : 
clay or soil, bamboos, thatch, etc. varied depending on the variation of altitude and geological formation.

\section{Origin and Development of Architecture}

The origin and development of architecture were side-by-side, since the evolution of man. Initially the human beings had no knowledge about how to build permanent dwellings. In the primitive stages, the human beings were nomads. They frequently travelled individually from one place to another gathering for food and flesh. They had no family as such but happily survived their life individually. When, the human beings had suffered from the scarcity of food and flesh, they felt insecure from the fierce animals and theft of their stored flesh and food, then they had begun to form groups. Before formation of groups, the human beings were hunting the wild animals individually. After the numerous kinds of incidents, in order to protect their life, they had formed initial hunting groups. Finally, they felt the power of groups and started to live together, dining together, and hunting together. Thereafter, the groups were converted into number of families, but reside in the same territory with their own separate house.

The human being had fortified their shelter in the beginning of civilization. They had created and applied defensive type of stone masonry wall without mortar as well as roof and proper openings. The houses were constructed against the theft of goods and commodities and deleterious animals. Similarly, the houses provide safety from rain, hot, and cold weather. The native people had practiced various models and forms of building where the people feel safer than the previous constructions. The materials of construction were favourable to the climate, weather, and topography. The first settlement was Memphis of Egypt. The city was completely fortified with wall using sun dried clay brick and timber (Davis, 1957, p. 22).

Architecture is the art and science of designing and building structures, communities, or open areas, in keeping with aesthetic and functional criteria (Harris, 1975, p. 51). Architecture is kind of arts and design created by the man for the man, i.e. icons, ornaments, pottery, fine arts, as well as shelters. Each kind of creation is a commemorative remembrance and the people are eager to make the replica of its original or masterpiece. The aesthetic dimension plays an enormous role to its fame of the architecture. The people of that period had developed some guideline of the building construction, philosophy, or technology for the construction, and they used the material for the aesthetic dimension.

Architecture is the philosophy of process and design of construction. The house is a basic need of the human beings. The geography and climate are always influencing the construction of houses. The religion, elevation of the land, vegetation, availability of indigenous construction material, ethnicity, religious values, and social norms etc. are the influencing factor in the construction of houses. The society accepted architecture varies according to locality and ethnicity. So, a permanent structural form built using indigenous construction material familiar with climates in the geographical region is architecture. 


\section{Schools of Nepalese Architecture}

The territory of Nepal is classified into four separate architectural zones. Each zone has its distinctive and separate architectural forms with individual isolated character. The peoples reside in each zone have their own specific peculiar skills and technology used indigenous construction materials to construct their houses since the date of origin. This kind of architectural forms and patterns were practiced separately using indigenous materials, skills, and techniques of construction with its own specific characteristics. The architectural forms and patterns are isolated from each other, but side by side developed and practiced with modification over the time since the date of origin. This is the reason,I have named 'School of Nepalese architecture'. Each school has transformed its own distinctive features and characteristics from generation to generation called 'Nepal's Origin Architecture'. The school of architecture is distinguishedin its use of construction material, skill, techniques, technology, form etc. including the aspiration of the human being on the geographical strata. According to the practice of architectural form in the geographical strata it can be;

\section{i. School of Khasa Architecture \\ ii. School of Tarāi Architecture \\ iii. School of Nepalese Architecture \\ iv. School of Mud Architecture \\ i. School of Khasa Architecture}

The architectural style developed and practiced in the Midwestern hilly region of Nepal called Khasa style (Khanal, 2055 BS, p. 3). The Khasa style of architecture has its own philosophy and design pattern followed and practiced by the people of the Midwestern hilly region. Khasa architecture is diffused from its place of origin, Sinja Valley, to the eastern and the western hilly region of Nepal. The Khasa architecture was diffused with proper modification to the eastern hilly region of Nepal.

Kuduleghar or Golghar or Ghumāuneghar is an example of diffused Khasa architecture. The Golghar has an aerodynamic character so, it can easily resist the air blown along the wall. It has numerous interconnected joints which gives the combination of flexibility with strength. Therefore, the generated all structural loads can easily transmit to the ground and get relief or zero potential.

The architecture shows the richness or poorness of any civilization. Apparently, Jumlā was also rich in architecture. Currently, Jumlā has lots of remnants of architectural fragments. Carried out by the Cambridge Archaeological Unit, the Sinja Valley Excavation in 2000 AD (2003) had documented decorative architectural fragments, sculpted remains, pipe irrigation systems and an extraordinary array of small finds (e.g. Copper alloy tablets and figurines). Moreover, the excavation team also found eight lion sculptures and several standing 'hero' stones (inscribed) (Evans, 2003, p. 15).

There were various Shikhara style temples, called Deval, constructed using of indigenous construction materials, especially stone. Similarly, there were various water tanks, Mangarāo, 
also constructed by the contemporary ruler. The stone spout (Mangarāo of Kaipālalmāndo of Dadeldhurā District constructed during the reign period of NāgiMalla), wells, cremation centre of Ajayameru fort, and other remains of other 12th -14th century AD monuments were also constructed in the Khasa Kingdom. The king Ashok Challa had constructed Shivālaya and KānkreVihārof Surkhet, Ukumahal, Ajmerumahal, Panchadevalof Bhurtikā, and Nāulain his kingdom (Subedi, 2061BS, pp. 85-86). Prithvi Malla constructed the various aesthetic monuments in Sinja Valley and the surrounding locations (Subedi, 2061BS, pp. 92-93). The land was named/classified as Nauli, Jiulo, Ālo, Bato, Pāto, Tāro, Pākho, Patto, etc. for convenience to collect the tax (Subedi, 2061 BS, p. 95).

The housing pattern of the Jumlā and other localities of the Sinja valley are similar. The houses are made of indigenous construction material of stone with or without dressing, single storey flat mud roof. The roof is liked to be a pellet form. Generally, there are no windows as to the wind blowing direction built the proper ventilation were provided. The thick stone masonry walls up to 3'-0" with mud mortar is available. The thicker wall prevents the cold and easily transmits the snow load. All kinds of indigenous construction material are used to construct the houses and other structure. The building wall easily bears the excess load of mud roof and transmits to the ground to convert the zero potential. So, the building exists for a long time.

\begin{tabular}{|c|}
\hline \multicolumn{2}{|c|}{ Mud layer up to 9" } \\
\hline Tay planks \\
\hline Timber Joists, 2.5"x3" \\
\hline
\end{tabular}

\section{Sketch: Flat mud roof, Drawn by SH Thapa}

The height of the traditional building of the Khasa kingdom of Western Nepal is not considerable. Generally, local people have constructed their house using indigenous construction material of timber lath (Planks), stone masonry with mud mortar, and timber elements of doors, windows, timber flooring, and roofing. The room height of the Khasa house is $1.6 \mathrm{~m}$ in general. An interesting matter of the building construction in the upper Himalaya including Jumlā, Humlā, and Dolpā, a flat mud roof is seen till now. The boulder mix soil has the properties of the water holding capacity for a time. The records of Metrology Department, Government of Nepal, indicate the precipitation in the Jumlā, Humlā, and Dolpā, Mustāng, and Manāng is very low but, heavy snowfall. After the heavy snow fall people has removed the snow deposited to their roof. Mud has a thermal character so it can resist heat and cold so, the internal temperature of the building is maintained. 
Sinja was the center of Khasa civilization. This center has developed various cultures as well as the linguistics called KhasaBhāshā (language), this language becomes the national language of Nepal called Nepali Language. The Khasa kings were keen to organize and construct the structure of pāti, temple, deval, nāula (step well),mangarāo, chautāri, tunnel, pillar (khamba), meeting/waiting pavilion, cave, as well as various monuments of stone. The architecture developed in the Karnāli basin is called Khasa architecture (Subedi, 2061 BS, p. 95). The existing buildings of stone masonry wall with mud mortar, flat mud roofing / slate roofing, required openings (10\%), and simple carvings with the consideration of climate, people's willingness and availability of construction materials. These kinds of architecture were developed in the beginning of Khasa Kingdom and were continuously followed and practiced till this time by the Khasa people. When the Khasa people migrates to the same geographical region they have practiced their own architectural form to the newly reside area. Therefore, it is an individual school of architecture.

\section{ii. School of Tarāi Architecture}

The architecture of the Nepal Tarāi is very simple. The material availability in the terai is properly used to build a house as per the needs and capacity of the people. An isolated cell of the house is mostly practiced adjusting the hot and humid temperature. Mud and bamboo are the basic material of these school. Thatch is use for the roofing material. The skillfully builtshelter is generally thermal insulation.

The buildings of Simroungadh and adjacent areas have distinctive features and characteristics. The available material and its proper use are considerable to the thermal insulation. The internal temperature was maintained in the hot and cold season. The annual temperature variation in the Tarāi is approximately $40^{\circ} \mathrm{c}$. The mud wall and the thatch roof play a vital role in maintaining the thermal insulation. The mud and the thatches are considered as thermal insulators.

The inhabitants of the Tarāi were residing together with almost the same kinds of architectural pattern using the construction materials of clay and bamboo. The walls of Tarāi buildings are made of tâti positioned vertically and tied to the bamboo or timber post and mud plastered on the both sides. The façade is white washed in general and painted with auspicious trees, plants, animals, and birds. The openings of the wall are like a weep hole except door. It is meant for air circulation rather than the light. This kind of architectural form is a different isolate school of architecture called Architecture of Tarāi. Which represents the inhabitants of the Tarāi of Nepal.

\section{iii. School of Nepalese Architecture}

The arts and architecture of Nepal Mandala are always panoramic. When the migrated peoples had selected the land for permanent dwellings in Nepal Mandala, then the artisan had begun to create various aesthetic arts and architectural form as they desire. The artisan had used various technologies and material to create an aesthetic building from the earlier 
history of Nepal. The archaeologists had not clarified the remaining of Lichchhavi house and its construction materials. However, baked brick, stone and timber were the most common construction materials in the Lichchhavi period.

The Kathmandu Valley itself is an abode of all cultural excellences, through simple but marvellous stupa, lofty and beautifully designed pagodas, richly carved doorways and windows, finely gilded roofs, magnificent pillars, and awe-inspiring Buddha images, which are the pride and glory of that period (Regmi, 1965, p. 23). The architecture developed and practiced in the Kathmandu is always alluring. The whole architectural form is dominated by the system and the principle of construction of the hilly region. The architectural form developed with specific design and using advanced material developed as to reduction of earthquake vulnerability in Kathmandu Valley. Such kinds of architecture practiced by the people of Kathmandu Valley, called Newar, using baked brick, mud/lime mortar, load transferable timber in the columns and beam, projected windows and other aesthetic forms. The wall is built as rigidity and thermal insulation with complete privacy. The slanting roof is covered with Jhingati/ thatch.

The literature published by the varioustravelers, missionaries, and historians the architectural form of the Nepal mandala is not comparable to other cities of the world. Its specific character of its cultural heritage and natural beauty at that time. The cultural heritage of the city such as stone spouts, palace, wide road paved with stone or baked brick. Bhandarkhāl (garden) mentioned in his autobiography (Mishra, 2060 BS, p. 50). Similarly, the travel account of father Giuseppe (17th century AD) depicted the city of Kathmandu Valley was clean and properly managed with rows of houses made using fine brick and carved timber elements. The houses are of 3 to 4 storey and usually the rooms were small. The footpath was properly paved with baked brick, tile or stone, or slate and drained off (Giuseppe, 1799, pp 307-322). Hence, the architecture practiced in the Nepal mandal is one isolated school of architecture.

\section{iv. School of Mud Architecture}

The upper Himalayan belt of Nepal has its own kinds of architectural form. The architectural form is created by the solidified mud wall with flat mud roof up to 5 storey. Kāgbeni is the center of the mud architecture. The numerous mud structure is still existing in the Kāgbeni. Such kind of architectural form is diffused to all upper Himalayan belt of Dārchulā to Kimāthānkā.

The architecture created to construct buildings using mud in Nepal prevailed since the prehistoric period. Everywhere in the nation, mud is the major construction materials to build the house. We have remains of the earthen architecture in the Mustāng as caves on the cliffs of the hills about the height 155 feet above the terrace. There are numerous caves built as human shelters before 700 years ago. The archaeological team has found and identified various artefacts from the caves. The caves are found in the systematic manner. 
The walls of the cave are decorated with wall paintings (Bond, Daily Mail, August 27, 2013). The caves, in general were natural but some of the caves were built by the rock cut (Ajanta cave) and the caves found in the upper Himalayan belt of Nepal were built in sandy soil cliff. According to the Archaeologist Sukra Sagar Shresthathe structure of the cave seems well planned and managed (an informal conversation).

It is noted that the Lho-Manthāng bounded by the earthen wall of 2 meters wide and 8 meters' height with the sediment of wet mud used mould made with the local technology. The compound walls of the city are 280-meter NS and 160-meter EW. It has only one main gate for the security as well as to make easier to collect the revenue from the traders and to grant permission to visit the city. The temperature variation of the city is $40^{\circ}$ centigrade $\left(20^{\circ}\right.$ centigrade in summer and $-20^{\circ}$ in winter). The architecture was developed people to maintain the excess variation of temperature and cool breeze passed through the area has evolved the mud architecture. The mud architecture's thermal comfort maintaining characteristics has been proved. The wall and the roof of the structures are of made of mud in this area.

Lho-Manthāng was the wall fortified capital of the Kingdom of Lho from its founding in $1380 \mathrm{AD}$ by Ame Pal who oversaw construction the city of mud wall and many of them are still-standing structures (Peissel, 1992, pp. 227-231). It is in the middle of the northwest of Nepal with bordering Tibet at the elevation of $3720 \mathrm{~m}$. above the MSL. Lho-Manthāng is known as the city of clay of Nepal. The city was developed with the earthen houses to protect from cold and cool air blowing from the ThakKhola. The land in the shadow area lies within the coordinates of $29^{\circ} 10^{\prime} 59^{\prime \prime} \mathrm{N}$ and $83^{\circ} 57^{\prime} 24^{\prime \prime} \mathrm{E}$ / 29.18306; 83.95667 and the mean temperature in about (-) 200 c. to +200 c. Where almost throughout the year heavy cold due to the snowfall and shadow area of the Annapurna and Dhaulagiri Himalayan range. The city was completely fortified with the mud wall around about 2 meters wide and 8-meter height. The houses are built with mud walls and flat mud roof. The mud of the Lho-Manthāng is hardened by the sunny day and very slightly melts in the rainy days; the annual rainfall of this area is recorded as $184 \mathrm{~mm}$ to $200 \mathrm{~mm}$ (Department of metrology, Ministry of Science and Technology, Governmentof Nepal).

Lho is the homeland of Thakalis who speak a different language and have a synthesis of Tibetan and Nepalese culture. The wall structure of Lho-Manthāng is very specific and different form. The wall was built in the 13th century AD by the solidified of clayey of local soil, boulder mix sand and clay, using traditional temporary wooden mould. This earthen wall is more durable and higherrise to 50 feet of 6-7 storey. There are series of numerous caves discovered and decorated with ancient Buddhist paintings and set in sheer cliffs at 14,000 feet $(4,300 \mathrm{~m})$ elevation. The paintings show Newari influence, dating to approximately 13th century and consists of Tibetan scripts executed in ink, silver and gold and pre-Christian era pottery shards. 
Table: School of Nepalese architecture

\begin{tabular}{|c|c|c|}
\hline School & $\begin{array}{c}\text { Origin and } \\
\text { practiced area }\end{array}$ & Material used \\
\hline $\begin{array}{l}\text { Khasa } \\
\text { Architecture }\end{array}$ & $\begin{array}{l}\text { Sinja/Dullu } \\
\text { centre }\end{array}$ & $\begin{array}{l}\text { Stone masonry wall with mud mortar, slightly slanted roof } \\
\text { somewhere flat mud floor, timber joist, minimum opening } \\
(10 \%) \text {, dispersed settlement. The wall is thermal insulation. }\end{array}$ \\
\hline $\begin{array}{l}\text { Tarāi } \\
\text { Architecture }\end{array}$ & $\begin{array}{l}\text { Simaroungadh } \\
\text { centre }\end{array}$ & $\begin{array}{l}\text { Mud plastered both sides of täti frame wall, sloped roof with } \\
\text { Khapda or thatch covering. Individual cell for individual } \\
\text { rooms, clustered settlements and hamlet, the wall is thermal } \\
\text { insulation. }\end{array}$ \\
\hline $\begin{array}{l}\text { Nepalese } \\
\text { Architecture }\end{array}$ & $\begin{array}{l}\text { Kathmandu } \\
\text { Valley }\end{array}$ & 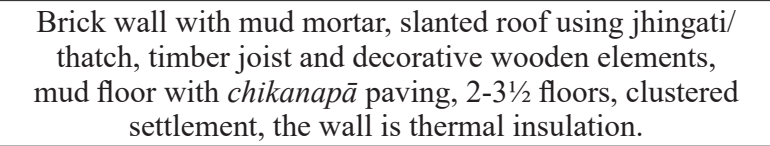 \\
\hline $\begin{array}{l}\text { Mud } \\
\text { Architecture }\end{array}$ & $\begin{array}{l}\text { Kāgbeni, Lo- } \\
\text { manthāng }\end{array}$ & $\begin{array}{l}\text { Mud wall and flat mud roof up to } 5 \text { storey and the wall is } \\
\text { thermal insulation. }\end{array}$ \\
\hline
\end{tabular}

The travellers, pilgrimages, and the traders had diffused the architectural features and skills of construction from one place to another.

\section{Conclusion}

Architecture is the science of arts, which deals with living space for human beings as functional, social, and aesthetic dimensions. The proper management of space is an architecture, which is always satisfied of its functional and social dimension. Mud is the basic material of each school of Nepalese architecture including other supporting construction materials. The Nepalese architects have planned and created the cities with functional, social, and aesthetic dimensions. The architects created and managed internal or external functioning area using the indigenous construction material as per the demands and desire of the owners, availability of construction material, used of indigenous skill, techniques and technology familiarize with the climate. The buildings characteristics of each schools were periodically modified, remoulding, and reformed since the preLichchhavi period to this date. This is a continuous process; this is because architecture is a cultural entity of a local or common society. ${ }^{2}$

2 Bond, A. (27 August 2013). Mystery of the ancient kingdom discovered in Nepal. Daily Mail (Online),http://www.dailymail.co.uk/news/article-2403094/Mystery-ancient-caves-Nepal. html, Retrieved August 27, 2013.

Centre bureau of Nepal, (2011). Census report. http://cbs.gov.np, Retrieved December 12, 2014.

Davis, H. A. (1957). An outline of the history. Great Britain: Oxford University Press.

Evans, C. (2003). The Sinja valley excavation in 2000 AD. Ancient Nepal. (153, p. 15). Kathmandu: Department of Archaeology.

Giuseppe, (Fr.) (1799). An account of the kingdom of Nepal. Asiatic Researches. Vol 2. (1799). pp. 307-322.

Harris, C.M. (1975). (Ed.) Dictionary of architecture and construction (4 $4^{\text {th }}$ Edition, 2006). New York: Mc-Graw Hills \& Co.

Khanal, M. P. (2052 BS). Nepālikalā (Nepalese arts). Kirtipur: CNAS, Tribhuvan University

Mishra, T. R. (2060 BS). (Ed.) Dharmaswāmikojiwani(Biography of Dharmaswami). Kathmandu: Lumbini Publication.

Peissel, M. (1992). Mustāng - A lost Tibetan kingdom. (2nd Ed.). Delhi: Book Faith India.

Regmi, D. R. (1965). Medieval Nepal, volume I. New Delhi: Rupa \& Co.

Shrestha, S. H. (2004). Economic geography of Nepal. Kathmandu: Educational Publishing House.

Subedi, R.R. (2061 BS). Nepālkotathyaitihās (Factual history of Nepal). Lalitpur: Shajha Prakashan. 